Article

\title{
How Do Energy Use and Climate Change Affect Fast-Start Finance? A Cross-Country Empirical Investigation
}

\author{
Renato Passaro ${ }^{1}\left(\mathbb{D}\right.$, Ivana Quinto ${ }^{2}$, Giuseppe Scandurra ${ }^{3, * \mathbb{C}}$ and Antonio Thomas ${ }^{1}$ \\ 1 Department of Engineering, University of Naples Parthenope, 80143 Napoli, Italy; \\ renato.passaro@uniparthenope.it (R.P.); antonio.thomas@uniparthenope.it (A.T.) \\ 2 Department of Industrial Engineering, University of Naples Federico II, 80125 Napoli, Italy; \\ ivana.quinto@unina.it \\ 3 Department of Management and Quantitative Studies, University of Naples Parthenope, 80132 Napoli, Italy \\ * Correspondence: giuseppe.scandurra@uniparthenope.it
}

Received: 21 October 2020; Accepted: 16 November 2020; Published: 19 November 2020

check for updates

\begin{abstract}
To promote the sustainable development of developing countries through the reduction of greenhouse gas emissions and the impact of anthropogenic activity on the atmosphere, for some decades, developed countries and international institutions provided an increasing amount of climate financing tools, allocated through multiple channels. After the Copenhagen Conference of the Parties (COP15) held in 2009, developed country parties pledged to provide new and additional resources, including forestry and investments, approaching USD 30 billion for the period 2010-2012 and with balanced allocation between mitigation and adaptation. This collective commitment has come to be known as "Fast-start Finance" (FSF). To assess the key factors contributing to the amount and distribution of funding supporting projects using FSF, in this paper, we investigate the relationship between FSF, energy use, and greenhouse gas emissions. To this aim, two main analyses were carried out: (i) a qualitative examination of donor's funding strategies and (ii) a quantitative analysis deepening the relationship between climate finance and greenhouse gas emissions by beneficiaries through a quantile regression model. Findings indicate a need to redesign the current aid scheme, and suggest an increasing need for financed projects to support sustainable economic innovation patterns of developing countries while paying close attention to the environmental policy context. The purpose was to provide useful feedback to policymakers to assess the effectiveness of the flow of funding for environmental plans and to avoid excessive aid dispersal and consequently a reduction of the FSF benefits.
\end{abstract}

Keywords: climate finance; Fast-start Finance; developing countries; renewable energy generation; greenhouse emissions

\section{Introduction}

The current dominant economic system led by developed countries has proven to be no longer sustainable; at least along the social and environmental dimension due to the negative externalities it generates. The anthropogenic activities resulting from this system has contributed to the breaching of several ecological boundaries, in relation to climate change, biodiversity loss, and environmental degradation [1-3]. One way to combat the effects of anthropogenic activities on the environment is a greater deployment of renewable energy sources (RESs) and wiser use of natural resources [4-8]. 
The common risks associated with climate change and the need to limit the impact of anthropogenic activities in the atmosphere were only recognized internationally in 1997 during the 3rd Conference of the Parties held in Kyoto in 1997. The final protocol signed by countries represents a corner-stone for the subsequent actions to promote the reduction of greenhouse gases (GHG) emissions. The Kyoto protocol provided for the creation of two sets of countries: developed countries (Annex I) which are obligated to reduce their GHG emissions and developing countries (Non-Annex I), which do not have emission reduction obligations.

Flexible mechanisms were included in the same Protocol to enable developed countries to meet their GHG reduction targets by purchasing emission reductions from other countries. In particular, two different mechanisms were included. A former, which allowed for the possibility of purchasing emission reductions from financial exchanges (such as the EU emission trading scheme) and a latter through the implementation of projects which reduce the emissions in non-Annex 1 countries under the Clean Development Mechanism (CDM). However, this innovative source has not reached the desired scale, in part because of the current weakness of the carbon markets and the lack of a coherent carbon pricing $[9,10]$ as well as because of limited or inadequate regulatory frameworks and policy support initiatives [11].

The objectives of contrasting the effects of climate change are more complex to achieve in developing countries where the problem of environmental protection, and harmful emissions in particular, is subordinated to other economic and resource scarcity priorities which involve related social phenomena like migration from rural areas and the huge increase of megacities and urban agglomerates size by means slums and squatter settlements [12].

For this reason, during the 15th Conference of the Parties (COP15) held in Copenhagen in December 2009, developed countries agree on the need to allocate additional resources (or funds) to counter the effects of climate change and promote economic growth in developing countries. This common commitment, known as Fast-Start Finance (FSF), prefigured the launch of the Green Climate Fund (GCF), a financial mechanism to reduce GHG emissions in developing countries. The GCF was established in 2011 during the COP17 held in Durban by the 194 member countries of the United Nations Framework Convention on Climate Change (UNFCCC), to support a paradigm shift in the global response to climate change. The purpose is to encourage the introduction of new technologies that allow a reduction of GHG and favor the transition towards the adoption of renewable energy sources with low environmental impact in developing countries.

As the resources allocated for this purpose have increased over the years, while new needs are constantly emerging, a new research stream has arisen to understand the effectiveness of funds and financial instruments in achieving the aforementioned purpose, as well as the underlying logic and criteria for the allocation of financial resources [13-15]. Anyway, despite several seminal articles on climate finance, the assessment of the role of GHG emissions and other key factors on climate funds flowing to developing countries has not been adequately examined [16-18].

Specifically, both the countries to target and the funding amount are the most important design choices, which are often a cause for disagreement among the international aid agencies as well as among developing countries' environment and finance ministries [19-21]. To help policymakers address, plan, and better target climate funding for long-term projects, further research on this issue is required $[20,22,23]$.

To contribute to filling this knowledge gap, in this study, we investigate the relationship between GHG emissions and energy use on climate finance to assess how GHG emissions and RES affect the amount of funding provided by developed countries.

To achieve our goals, a twofold analysis was performed using a large dataset of 97 countries (16 developed-i.e., donors-and 81 developing-i.e., recipients—countries). First, we analyzed the funding distribution dynamic to uncover preferential channels among donors towards certain recipient countries by assessing the funding concentration. Second, we focused on the 81 recipients countries and investigated the determinants of the funding flow by assessing: (i) the effect of the concentration in 
the Fast-Start Finance distribution, and (ii) how Fast-Start Finance is affected by both the anthropogenic impact on the environment and by energy use, applying a quantile regression model.

The findings of this investigation can contribute to the ongoing debate on the vulnerability and resilience of developing countries, thus supporting policymakers to ensure the greatest levels of equality both in terms of funding amounts, and of GHG emission reduction, improving the efficacy of the funds themselves.

The remainder of the paper is organized as follows. Section 2 reports the framework and Section 3 describes the flow of funding among countries. Then, Section 4 reports methods and data. In Section 5 the results are discussed. Conclusions and policy implications are illustrated in Section 6.

\section{Framework}

The Fast-Start financing mechanism was one of the first examples of an international cooperation system able to provide financial assistance to promote projects to combat the effect of climate change and to promote investments in green energy generation. It is a precursor to the GCF, first proposed during the Conference of the Parties (COP15, Copenhagen, 2009), and launched at COP17 (Durban, 2011), when the developed countries pledged to jointly provide USD 100 billion annually by 2020 to developing countries. Moreover, to support the global objectives of safeguarding the environment, during the COP21 (Paris, 2015) to the UNFCCC, the international community endorsed a climate agreement, known as the Paris Agreement. This understanding has resulted in the adoption of the first international agreement to limit the increase in global temperature. It takes into account: (i) adaptation, i.e., actions taken to help communities and ecosystems manage changing climate conditions and (ii) mitigation, which aims to constantly reduce GHG emissions [24]. One of the operating entities adopted is the GCF, which represents a financial mechanism to address international climate finance.

At COP15, the developed countries guaranteed immediate Fast-Start Finance of up to USD 30 billion over 2010-2012 to launch the GCF project [25]. Such financing initiatives can support developing nations by enabling them to move towards low-emission and climate-resilient development pathways. With Fast-Start funding, Annex II Parties, Annex I minus the East European countries and Russian "economies in transition" under the Kyoto Protocol are required to provide financial resources to enable developing countries (Non-Annex-I) to undertake emission reduction activities and to help them adapt to the adverse effects of climate change.

Within this background, many authors have debated the potential of international cooperation to promote economic growth and reduce its environmental impact by promoting green electricity generation [10]. Nakhooda et al. [19] maintain that without adequate financial support, i.e., financiers that bear the costs of RES deployment, the governments of developing countries would prefer to choose economic growth (to generate jobs and reduce poverty) instead of climate protection. Hence, financial cooperation among the developed countries is crucial to help poor countries to overcome endogenous resource limits, by creating new incentives for low carbon development and to support policies to build resilience systems against the risks caused by climate change.

However, it is currently believed that investing in renewable energy often does not conflict with alternative uses of resources. Indeed, it can favor the transition toward sustainable development [26-28]. Keeley [29] and Espagne [30] detail a list of the difficulties that developing countries face in developing their economic systems without using carbon fossil sources and mainly relying on the financial support of developed countries. For instance, often projects fail due to the lack of internationally recognized indices and criteria to compare projects across countries [31].

Many researchers $[4,17,32]$ also argued that a country's economic development depends on how aid is organized and distributed to develop a sustainable system of energy production and to optimize the power transmission and the distribution of electricity grid, which is mostly lacking in the developing countries. Nonetheless, as in a vicious circuit, one of the primary obstacles to radically improving energy-access investments in these countries is poverty $[18,33]$. Hence, dedicated external funds are necessary, and an issue about how to maximize the efficacy of these funds emerges [34-36]. 
Recently, Carfora and Scandurra [23] assessed the impact of climate funds analyzing the aid received by the recipient countries through a counterfactual analysis based on propensity score matching. They show that climate policies contribute to reduce GHG emissions and promote the substitution of traditional (fossil) generation sources with RES.

From the donors' side, Halimanjaya and Papyrakis [37] have analyzed the link between the characteristics of donor countries and the share of funds allocated to climate mitigation finance, by examining a panel dataset of 22 donor countries in the period 1998-2009. They find that donors with a larger green domestic budget tend to allocate a smaller portion of overseas aid to mitigation finance. The opposite holds for donor countries with better institutions and governance that have ratified the Kyoto Protocol. From the beneficiaries' side, by studying the relationship between aid allocation and vulnerability, Betzold and Weiler [38] found that countries more vulnerable to the effect of climate change receive more support by adaptation aid.

Anyway, serious trouble with the management of financial aid emerges. Several scholars $[14,39]$ have emphasized the importance of intragovernmental coordination by proposing a balanced, supranational organization to manage climate funding to avoid the expensive duplication of projects. In addition, they sustain the importance of shifting the focus of donors and recipients from funding amounts to strategically analyzing needs and opportunities.

Other researchers e.g., [40] assessed the need to lead developing countries towards a low-carbon economy through a gradual process that enables the consequences of changes to be tested. While the necessity to investigate how climate finance effectiveness is monitored and evaluated in different communities is sustained by other contributes [18,41].

From an empirical perspective, Tirpak et al. [42] present nine technical, political, and capacity challenges faced by developing countries in Asia, Africa, and Latin America. They outline some of the steps that developing countries and their international partners can take toward monitoring and tracking climate finance more effectively.

Despite these influential researches, many issues about aid efficacy remain unsolved or have not been considered at all. In particular, the relationships between Fast-Start Finance and the funding flows addressed to sustain RES investment initiatives and reduce GHG are poorly analyzed. The next sections are addresses to shed light on this issue.

\section{Dynamic of Fast-Start Finance}

In this section, we present an overview of the distribution of funding pledged through Fast-Start Finance, by analyzing the disbursement flows and their concentration. Table 1 reports the directions of the funding flows and their amounts with a summary of the main disbursement in 2010.

Since commitments alone are insufficient for evaluating effectiveness [43], data refers to the AidData Research Release 2.1 (of whom the most recent year is 2010), because the disbursements are not made available in AidDataCore_ResearchRelease_Level1_v3.0 (Released: 29 April 2016), which is primarily a commitment database. We considered funding destined for "Energy generation and supply", which include power-generation/renewable sources and policy, planning, development programs, surveys and incentives, and funding targeted at "General environmental protection", which denote biosphere protection and involve air-pollution control, ozone-layer preservation, and marine pollution control $[13,44]$. We excluded the amounts loaned by international programs and/or destined for regions or areas of the world. Even though these data are limited to one year, they are representative of a systematic policy program involving many countries. Furthermore, shedding light on the relationship between climate finance, climate change, and energy consumption is key to provide donor countries with appropriate feedback to drive their further intervention plans to support developing countries to reduce greenhouse gas emissions, while promoting their sustainable development. 
Table 1. Amount of "Fast Start Finance".

\begin{tabular}{|c|c|c|c|c|c|c|c|}
\hline Quantiles & Recipients & $\begin{array}{c}\text { Average } n^{\circ} \\
\text { Financed Projects }\end{array}$ & Total of Recipient * & Recipient/GT (\%) & $\begin{array}{c}\text { Recipient/GT of } \\
\text { Recipient }\end{array}$ & $\begin{array}{l}\text { Donor/GT of } \\
\text { Donor }\end{array}$ & Donor/GT \\
\hline 25 th & $\begin{array}{l}\text { Niger, Nigeria, Mali, Botswana, Iran, Vanuatu, } \\
\text { Guatemala, Lesotho, Angola, Bosnia and } \\
\text { Herzegovina, Syria, Eritrea, Venezuela, Namibia, } \\
\text { Malaysia, Sao Tome and Principe, Laos, Rwanda, } \\
\text { Belarus, Dominican Republic, Morocco }\end{array}$ & 1.81 & 0.04 & 0.02 & 90.88 & 5.47 & 10.57 \\
\hline 50 th & $\begin{array}{l}\text { Tonga, Malawi, Sri Lanka, El Salvador, Haiti, } \\
\text { Cameroon, Costa Rica, Uruguay, Colombia, } \\
\text { Ethiopia, Madagascar, Benin, Algeria, Ecuador, } \\
\text { Azerbaijan, Tajikistan, Yemen, Kenya, Jordan }\end{array}$ & 3.00 & 0.17 & 0.10 & 70.59 & 8.36 & 11.81 \\
\hline 75 th & $\begin{array}{c}\text { Lebanon, Paraguay, Mozambique, Honduras, } \\
\text { Panama, Papua New Guinea, Maldives, Nicaragua, } \\
\text { Pakistan, Cuba, Senegal, Ghana, Kazakhstan, Chile, } \\
\text { Tunisia, Argentina, Kyrgyzstan, Armenia, Mexico, } \\
\text { South Africa, Egypt }\end{array}$ & 4.19 & 0.66 & 0.41 & 69.93 & 12.01 & 10.37 \\
\hline 90th & $\begin{array}{l}\text { Tanzania, Thailand, Bolivia, Ukraine, Cape Verde, } \\
\text { Bangladesh, Cambodia, Vietnam, Zambia, Brazil, } \\
\text { Mongolia, Philippines }\end{array}$ & 8.08 & 1.74 & 1.07 & 55.58 & 18.78 & 8.35 \\
\hline 95th & Uganda, Indonesia, Peru & 9.67 & 3.66 & 2.25 & 72.48 & 34.50 & 5.72 \\
\hline Over 95th & Afghanistan, Nepal, China, India, Turkey & 19.40 & 22.59 & 13.88 & 63.32 & 48.83 & 19.35 \\
\hline
\end{tabular}

The distribution of countries follows the quantiles of the ratio between the average share of the funding obtained by the beneficiary and the total amount of the disbursement (Recipient/GT).

We have taken into consideration the usual quartile distribution (25th, 50th, and 75th), but we have focused on the countries that receive highest funds, i.e., those included in the 90th, 95th and over 95th percentiles. The column Total of Recipient represents the average of climate funds received by countries (in millions of US dollars); "Donor/GT" represents the mean share of resources of the donor of the total disbursement by all developed countries that participate in Climate Finance. The column "Donor/GT donor" reports the mean share of resources financed by the donor towards its main beneficiary of the amount of funding disbursed by the donor. Similarly, for the column "Recipient/GT recipient," we calculated the mean share of allocated funding from the donor of the total aid received aid for the main project. 
Moreover, the reason for this choice is linked to the fact that a robust assessment of the country characteristics influencing the distribution of climate funds is possible with disbursement data, and not with commitments. As highlighted in previous studies [35] there is a substantial difference between the disbursed and committed funds; commitments are higher than disbursements. Moreover, the samples include all the countries that received climate funds in 2010.

Following the UNFCCC, the dataset included: (i) Annex-II Parties of the Kyoto Protocol, which are required to provide financial resources to enable developing countries to undertake emissions reduction activities under the Convention and to help them adapt to the adverse effects of climate change; (ii) non-Annex-I Parties (including the least developed countries-LDC) and economies in transition (EIT, i.e., the Russian Federation, the Baltic States, and several Central and Eastern European states). Annex-II Parties consist of the Organization for Economic Co-operation and Development (OECD) members of Annex-I but not the EIT Parties. Data on recipient countries are reported in Appendix A.

We grouped the recipients in quantiles and sorted them in ascending order according to the total amount of main received aid from their main donors. The funding involved in our analysis is specifically concerned with environmental issues: (i) energy generation and supply and (ii) general environmental protection. Both types of aid are included in the funding directed to adaptation and mitigation policies to enforce the contrast to climate change. As suggested by Zhao et al. [45], this funding represents a contributing factor with respect to promoting investment in RES generation, alternative green energy use, and enhancing technological progress in environmental protection. The main flows are channeled to developing countries, which are characterized by fast-growing economies. In fact, in the last quantiles (i.e., the countries that received more funding), we found China, India, and Turkey. These countries primarily receive funding from European countries. However, the number of financed projects is substantially smaller than the number of projects in those countries funded by the United States.

Figure 1a shows a histogram of the funding distribution (overlaid with a normal and a kernel density distribution). The histogram reveals a strong asymmetry, which confirms that many developing countries receive a low amount of climate funding, while few countries concentrate a high share of funding. Concentration is also confirmed by the Lorenz curve in Figure $1 \mathrm{~b}$ and a related Gini index value of 0.828 (highlighting severe climate funds distribution inequality).

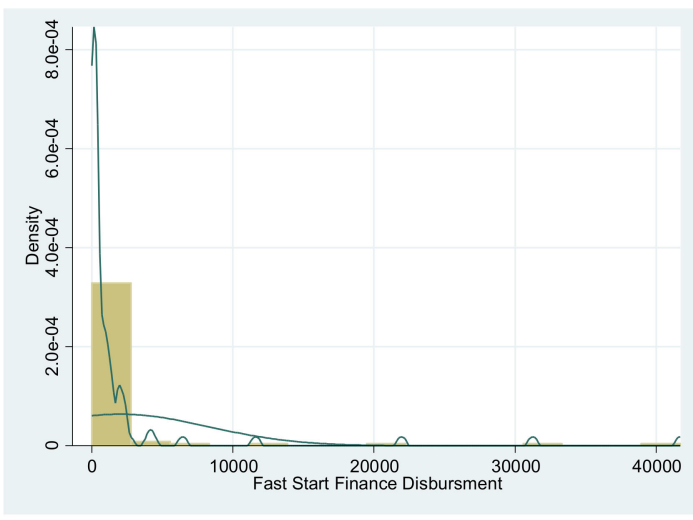

(a)

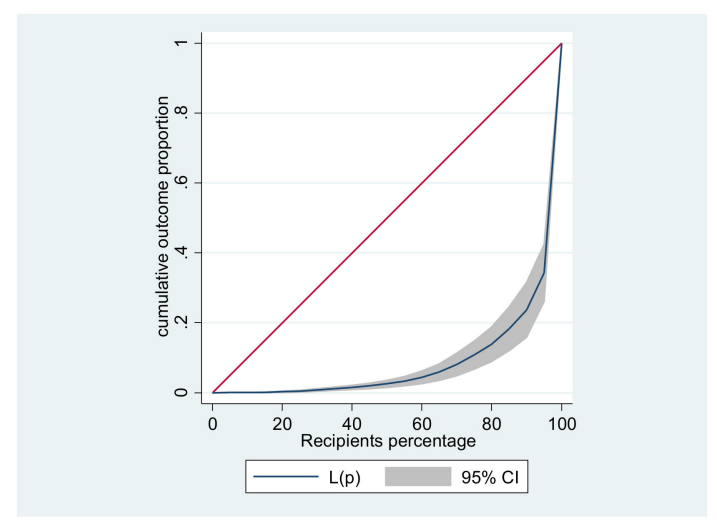

(b)

Figure 1. Distribution of Fast Start Finance in 2010: (a) histogram overlaid with a normal density (dashed line) and a kernel density (solid line) and (b) Lorenz curve.

Figure 1 shows that only $20 \%$ of the total amount of climate change funding is destined for approximately $90 \%$ of the countries. This outcome also means that approximately $10 \%$ of the recipients (only 8 of 81 countries) receive the remaining $80 \%$. Until the 90th percentile, the mean of total funding 
received by a recipient oscillates between $0.02 \%$ and $1.07 \%$, while only a few countries receive on average over $2 \%$ and up to $14 \%$ of the total amount of disbursements.

By analyzing Appendix B data, the main beneficiary of green climate funding appears to be Turkey (with $25.6 \%$ of the total received funding). It is primarily financed by European countries, particularly by France (approximately 99\% of FSF funding), which represents the world's largest provider of climate funding as it allocates $25.8 \%$ of total disbursements (approximately 162 million dollars). Of the total green climate funding provided to Turkey, approximately $25.6 \%$ of the total disbursement is within the competence of the Agence Française de Dévelopement [46] program, which aspires to fortify the French-Turkish partnership on climate and environmental issues and to preserve Mediterranean ecosystems while limiting GHG emissions. In particular, the AFD Group allocated approximately EUR 2 bn of financing between 2005 and 2015 in the country to promote low-carbon growth by supporting small and medium-sized enterprises via credit lines and to promote, preserve and develop natural resources.

The second-largest recipient country is India, which receives approximately $24.8 \%$ of the total funding made available by all developed countries. Over half of all financial resources (58.34\%) are allocated by Germany to promote environmental protection, energy projects and to address poverty, as well as social issues that remain challenging. In addition, the Deutsche Gesellschaft Für Internationale Zusammenarbeit (German Society for International Cooperation) contributes to numerous initiatives to address India's environmental and social changes.

In the ranking of the top recipients, China, with a budget of approximately USD 22 million (approximately 13\% of the total funding) is third, primarily financed by the United Kingdom; however, the number of projects is not always in line with the amount of the allocation. For instance, with 59 projects funded, China received slightly more than half of the total disbursement received by Turkey, which has only four "green-growth" projects. From a broader perspective, observing the Appendix B data, the 13 European countries cover about $80 \%$ of the total disbursed funds to developed countries that finance about $70 \%$ of the projects, while the remainder is provided by Japan (about $11 \%$ of disbursed funds), USA (about $8.5 \%$ ) and Canada (about $0.5 \%$ ). As for the beneficiary countries, European countries provide funding for $58 \%$ of these countries, while the USA and Japan respectively provide funding for about $11 \%$ and $27 \%$. In terms of average project size, they are USD $274,000,19,000$, and 61,000 for European countries, USA, and Japan, respectively.

Therefore, the number of projects in developing countries reflects the funding strategy of the donors (wide project support vs. concentration). In particular, the opposing funding distribution strategies of Europe and the other countries (especially the USA and Japan) emerge. The formers (except Germany) concentrate their aid on a few countries aiming to ensure substantial funding, while the latter supports a larger number of countries but with a limited amount of economic aid. Japan has an intermediate financing strategy although closer to the USA strategy.

\section{Method and Data}

In a strongly skewed distribution, as for climate funding (Figure 1a), it is better to estimate a quantile regression model, originally introduced by [47], rather than to use a usual regression model. The great advantage of quantile regression is that it can be used to examine the impact of covariates on the entire distribution. Additionally, it makes no distributional assumption regarding the error term, thus making it robust against heavy-tailed distributions and outliers. In other words, the quantile regression estimates the relationship between a set of covariates $X$ and the conditional quantiles of $Y$, and it is useful in those applications in which boundaries also become important $[48,49]$, as often it happens in environmental studies [50,51]. 
In this paper, the quantile regression was performed by minimizing the following equation from Parente and Santos Silva [52], which extends the results of the traditional quantile regression estimator proposed by Kim and White [53]:

$$
\hat{\beta}=\arg \min _{b} \frac{1}{G} \sum_{g=1}^{G}\left\{\sum_{y_{g i} \geq x_{g i}^{\prime} b} \alpha\left|y_{g i}-x_{g i}^{\prime} b\right|+\sum_{y_{g i}<x_{g i}^{\prime} b}(1-b)\left|y_{g i}-x_{g i}^{\prime} b\right|\right\}
$$

where $\alpha$ represents the generic $\alpha$-th quantile (with $0 \leq \alpha \leq 1$ ) of $y$ (the dependent variable) given $x$ (the covariates) and the $g$ indexes are a set of $G$ clusters, each composed of $n_{g}$ elements. Thus, using a consistent estimator of the covariance matrix, one can assume that the disturbances are conditionally independent across clusters, but can be correlated within clusters. Specifically, in the absence of intra-cluster correlation, the covariance estimator proposed by [52] is equivalent to a standard heteroscedasticity robust estimator, which is the case when $n_{g} \equiv 1[54,55]$.

Therefore, the model to be estimated is as follows:

$$
y_{g i}=x_{g i}^{\prime} \beta(\alpha)+u(\alpha)_{g i}
$$

where $\hat{\beta}(\alpha)$ is typically estimated using linear programming methods to take into account the economic and social structure of countries that might result in intra-cluster correlation. To identify the economic clusters, we used the World Bank's classification of countries (low, lower-middle, upper-middle, and high-income economies).

Due to the flexibility of the method and the lack of assumptions on the variables' distribution, quantile regression is playing a central role in studies related both to climate change [56] and to those more specifically related to climate finance e.g., [57]. Estimates are obtained using the statistical software Stata v14.

\section{Data}

Several institutional and environmental factors can be used to test how country characteristics affect the distribution of climate funds (specifically the concentration in the distribution of the funding provided by donor countries to support developing ones). For this reason, we performed an analysis using a wide set of control variables accounting for the main factors related to the adoption of green policies: environmental, socio-economic, energy, and demographic issues. The outcome variable summarizes the international climate funding distribution and represents the total amount of financial aid received by Non-Annex I countries.

Table 2 provides data definitions, sources, and the main descriptive statistics of the variables used in our analyses. 
Table 2. Data: Definitions, descriptive statistics, and sources.

\begin{tabular}{|c|c|c|c|c|c|c|c|c|}
\hline Variable & Definition & Unit & Year & Mean & Std. Dev. & Min & $\operatorname{Max}$ & Source \\
\hline \multicolumn{9}{|c|}{ Dependent Variable } \\
\hline QTot_rec & $\begin{array}{c}\begin{array}{c}\text { Sum of funds allocated to "Energy generation and supply" and to "General } \\
\text { environmental protection" }\end{array}\end{array}$ & $\mathrm{M} \$$ & 2010 & 2008.56 & 6264.07 & 3.06 & $41,710.38$ & AidData.org \\
\hline \multicolumn{9}{|c|}{ Covariates } \\
\hline Ghg_tot & $\begin{array}{l}\text { Total greenhouse gas emissions are composed of } \mathrm{CO}_{2} \text { totals excluding shortcycle } \\
\text { biomass burning (such as agricultural waste burning and } \\
\text { Savannah burning) but including other biomass burning (such as forest fires, post-burn } \\
\text { decay, peat fires and decay of drained peatlands), all anthropogenic } \mathrm{CH}_{4} \text { sources, } \mathrm{N}_{2} \mathrm{O} \\
\text { sources and F-gases (HFCs, } \mathrm{PFCs} \text { and } \mathrm{SF}_{6} \text { ). }\end{array}$ & $\begin{array}{l}\mathrm{kt} \text { of } \mathrm{CO}_{2} \\
\text { equivalent }\end{array}$ & 2010 & $332,428.20$ & $1,301,755$ & 151.93 & $11,200,000$ & $\begin{array}{l}\text { World Bank } \\
\text { (World } \\
\text { Development } \\
\text { Indicators) }\end{array}$ \\
\hline$e i$ & $\begin{array}{l}\text { Energy intensity level of primary energy is the ratio between energy supply and gross } \\
\text { domestic product measured at purchasing power parity. Energy intensity measures how } \\
\text { much energy is used to produce one unit of economic output. Lower ratio indicates that } \\
\text { a smaller amount of energy is used to produce one unit of output. }\end{array}$ & $\begin{array}{l}\mathrm{MJ} / \$ 2011 \\
\mathrm{PPP} \text { GDP }\end{array}$ & 2010 & 6.03 & 3.42 & 2.34 & 19.55 & $\begin{array}{l}\text { World Bank } \\
\text { (World } \\
\text { Development } \\
\text { Indicators) }\end{array}$ \\
\hline oil_sup & $\begin{array}{c}\text { Total Oil Supply includes the production of crude oil } \\
\text { (including lease condensate), natural gas plant liquids, and other liquids, and refinery } \\
\text { processing gain *. }\end{array}$ & $\begin{array}{l}\text { Thousand } \\
\text { Barrels Per } \\
\text { Day }\end{array}$ & 2010 & 416.88 & 923.75 & -0.545 & 4377.13 & The U.S. \\
\hline sh_foss & $\begin{array}{c}\begin{array}{c}\text { Fossil Fuels electricity generation consists of electricity generated from coal, petroleum, } \\
\text { and natural gas. }\end{array} \\
\end{array}$ & $\begin{array}{c}\text { Billion } \\
\text { Kilowatthours }\end{array}$ & 2010 & 0.60 & 0.34 & 0 & 1 & $\begin{array}{l}\text { Energy } \\
\text { Information } \\
\text { Administration }\end{array}$ \\
\hline sh_nonhydro & $\begin{array}{l}\text { Non-Hydroelectric renewable generation includes the electricity generated by wind, } \\
\text { solar, tide, wave and geothermal plants. It excludes generation from hydroelectric plants } \\
\text { and pumped storage }\end{array}$ & $\begin{array}{l}\text { Billion } \\
\text { Kilowatthours }\end{array}$ & 2010 & 0.03 & 0.06 & 0 & 0.30 & \\
\hline pop_fem & $\begin{array}{l}\text { Female population is the percentage of the population that is female. Population is based } \\
\text { on the de facto definition of population, which counts all residents regardless of legal } \\
\text { status or citizenship-except for refugees not permanently settled in the asylum country, } \\
\text { who are generally considered part of the population of the country of origin. }\end{array}$ & $\%$ of total & 2010 & 50.24 & 1.03 & 48.14 & 53.79 & $\begin{array}{l}\text { World Bank } \\
\text { (World } \\
\text { Development } \\
\text { Indicators) }\end{array}$ \\
\hline \multicolumn{9}{|c|}{ Socio-Economic and Living Standards } \\
\hline acc_el & $\begin{array}{l}\text { Access to electricity is the percentage of population with access to electricity. } \\
\text { Electrification data are collected from industry, national surveys and international } \\
\text { sources. }\end{array}$ & $\%$ of population & 2010 & 70.56 & 32.56 & 8.70 & 100 & $\begin{array}{l}\text { World Bank } \\
\text { (World } \\
\text { Development } \\
\text { Indicators) }\end{array}$ \\
\hline $\lg d p$ & $\begin{array}{l}\text { GDP per capita based on purchasing power parity (PPP). PPP GDP is gross domestic } \\
\text { product converted to international dollars using purchasing power parity rates. An } \\
\text { international dollar has the same purchasing power over GDP as the US dollar in the } \\
\text { United States }\end{array}$ & $\begin{array}{l}\text { constant } \\
2011 \text { international } \\
\$\end{array}$ & 2010 & 8.61 & 0.89 & 6.71 & 9.96 & $\begin{array}{l}\text { The U.S. } \\
\text { Energy } \\
\text { Information } \\
\text { Administration } \\
\text { (EIA) }\end{array}$ \\
\hline In_elcons & $\begin{array}{l}\text { The electric consumption is the electric power consumption equal to the sum of total net } \\
\text { electricity generation and electricity imports net of the electricity exports and electricity } \\
\text { transmission and distribution. } \\
\text { losses }\end{array}$ & $\begin{array}{l}\text { Billion } \\
\text { Kilowatthours }\end{array}$ & 2010 & 2.21 & 2.21 & -3.09 & 8.24 & $\begin{array}{l}\text { The U.S. } \\
\text { Energy } \\
\text { Information } \\
\text { Administration } \\
\text { (EIA) } \\
\end{array}$ \\
\hline
\end{tabular}

* Negative refinery processing gain data values indicate a net refinery processing loss. 
The first group of control variables captures environmental degradation due to economic development by considering the main anthropogenic emissions responsible for climate change (GHG).

The "energy" group focuses on the share of renewable (non-hydro) and fossil generation. Each of these variables has been obtained as the ratio of non-hydroelectric generation to total electricity production (sh_nonhydro) and the ratio of fossil fuel electricity generation to total electricity production (sh_foss), respectively [8]. We also include energy intensity (i.e., the ratio of energy consumption to GDP) (ei) since it can be considered a proxy of technological and economic progress [8]. Lastly, to control for lobbying effects [5,51], we investigate the effects of the oil supply as greater energy dependence on traditional sources could limit the attention to renewables. We expect an increase in the use of funding to reduce the dependency on a traditional source.

To take into account the preferences for greener policy management, we included the percentage of the female population as a proxy of environmental awareness in the "demographic" group. It has been pointed out $[45,58,59]$, for instance, that women show higher environmental concern and awareness about ecological issues than men. Because of their functions in households, women should be the primary beneficiaries of aid and measures to improve living conditions.

The last group considers the economic and structural indicators, namely the gross domestic product $(\lg d p)$ to control the related level of economic development, the percentage of the population with direct access to the power grid (acc_el) and electricity consumption (ln_elcons) as a proxy of a country's economic development [60]. Generally, as discussed in Section 2, countries can improve environmental conditions by increasing their investment in RES e.g., [61]. Therefore, the latter variable becomes essential for economic, political, and social development [44].

\section{Results and Discussion}

In the previous section, we showed that climate funding is focused on a few countries (Figure 1a). This evidence suggests the use of a quantile regression model [62] to assess whether and how the funding concentration of Fast-Start finance is affected by the impact of anthropogenic activity.

The estimated model is as follows:

$$
\begin{aligned}
& \text { QTot_rec }\left(\alpha \mid X_{g i}\right)=\beta_{0}(\alpha)+\beta_{1} \operatorname{ghg} \_t o t(\alpha)+\beta_{2} \text { pop_fem }(\alpha)+\beta_{3} e i(\alpha)+\beta_{4} \text { oil_sup }(\alpha)+ \\
& +\beta_{5} \text { sh_foss }(\alpha)+\beta_{6} \text { sh_nonhydro }(\alpha)+\beta_{7} \lg d p(\alpha)+\beta_{8} \operatorname{lnel} \_c o n s(\alpha)+\beta_{9} a c c \_e l(\alpha)+u(\alpha)
\end{aligned}
$$

where $\alpha$ shows the $\alpha$-th quantile, $\beta_{0}$ is the intercept, $\beta_{1}$ to $\beta_{9}$ are the slopes of the independent variables and $u$ is the error term. In the model, we assess the total funds $\left(Q_{\text {Tot_rec }}\right)$ for different quantiles $(\alpha=0.25$, $0.50,0.75,0.90,0.95)$ considering the presence of within-cluster dependence and obtaining confidence intervals for quantile regression estimators at any single quantile. For the 95th quantile, we have also estimated the model with heteroscedasticity-robust standard errors [63]. Except for the share of fossil energy, which becomes significant at $10 \%$, there are no significant differences between the two estimate models. This difference in the results of the conducted test is probably due to the homogeneity of the socio-economic structure of the countries in the last quantile.

To account for the social-economic structure of the countries, the sample has been clustered following the World Bank's Income Group.

\subsection{Key Factors of the Funding Distribution for the Quantiles}

Table 3 reports the estimated coefficients of Equation (3). 
Table 3. Quantile regression results.

\begin{tabular}{|c|c|c|c|c|c|}
\hline \multirow[b]{2}{*}{ Variable } & \multicolumn{5}{|c|}{ Quantile } \\
\hline & 25th & 50th & 75th & 90th & 95th \\
\hline & Coef./(se) & Coef./(se) & Coef./(se) & Coef./(se) & Coef./(se) \\
\hline \multirow[t]{2}{*}{ ghg_tot } & $0.00206^{* * *}$ & $0.00203^{* * *}$ & $0.00199 * * *$ & $0.00977^{* * *}$ & $0.0104^{* * *}$ \\
\hline & (0.0000319) & (0.0000228) & (0.0000505) & $(0.00203)$ & $(0.00117)$ \\
\hline \multirow[t]{2}{*}{ pop_fem } & -23.36 & -22.05 & -94.90 & $-346.8^{* * *}$ & $1048.9 * *$ \\
\hline & (29.78) & (57.34) & (91.58) & (109.5) & $(459.6)$ \\
\hline \multirow[t]{2}{*}{$e i$} & -10.66 & 17.06 & -60.07 & $-415.3^{* *}$ & -53.27 \\
\hline & (9.677) & (31.02) & (44.94) & $(179.2)$ & $(96.40)$ \\
\hline \multirow[t]{2}{*}{ oil_sup } & $-0.288^{* * *}$ & $-0.413^{* * *}$ & $-0.605^{* * *}$ & $-1.757^{* * *}$ & $-1.673^{* * *}$ \\
\hline & $(0.0395)$ & $(0.124)$ & $(0.190)$ & $(0.332)$ & $(0.437)$ \\
\hline \multirow[t]{2}{*}{ sh_foss } & $96.46^{*}$ & 344.5 ** & 143.1 & -429.8 & $-3206.5^{* *}$ \\
\hline & (57.16) & (158.3) & (392.7) & (2189.9) & $(1456.5)$ \\
\hline \multirow[t]{2}{*}{ sh_nonhydro } & 308.2 & -316.3 & $-2152.7^{* * *}$ & $-7075.9 *$ & $-23748.6^{* * * *}$ \\
\hline & (436.0) & (587.3) & $(700.0)$ & $(3899.8)$ & (4913.9) \\
\hline \multirow[t]{2}{*}{$\lg d p$} & -2.826 & -37.63 & -280.1 & -1217.3 & $-2996.0 * *$ \\
\hline & (40.62) & (81.83) & (408.2) & $(2736.4)$ & $(1145.7)$ \\
\hline \multirow[t]{2}{*}{ Inel_cons } & 7.219 & 75.51 & $235.9^{* * *}$ & 511.2 & 478.2 \\
\hline & (24.16) & (48.18) & (59.35) & (583.5) & $(470.7)$ \\
\hline \multirow[t]{2}{*}{ acc_el } & 1.579 & $2.443^{* * *}$ & 1.234 & -0.782 & 38.09 \\
\hline & (1.116) & $(0.803)$ & (7.936) & (52.92) & (28.77) \\
\hline \multirow[t]{2}{*}{ Constant } & 1115.7 & 1149.7 & 7915.2 ** & 32246.1 & -23721.8 \\
\hline & (1690.5) & (2569.4) & $(3243.1)$ & $(24516.0)$ & (14572.1) \\
\hline R-squared & 0.243 & 0.253 & 0.282 & 0.260 & 0.240 \\
\hline N. of cases & 81 & 81 & 81 & 81 & 81 \\
\hline $\begin{array}{c}\text { Parente-Santos Silva } \\
\text { test } p \text {-value }\end{array}$ & 0.706 & 0.821 & 0.925 & 0.317 & 0.000482 \\
\hline
\end{tabular}

Heteroscedasticity-robust standard errors are in parenthesis. ${ }^{*}$ Denotes statistical significance at $10 \% .{ }^{* *}$ Denotes statistical significance at $5 \% .{ }^{* * *}$ Denotes statistical significance at $1 \%$.

First, we observe that nearly all the coefficients are mean-reverting on lower quantiles and show a significant pattern change only for the last quantiles. Thus, the coefficients of the covariates increase, in absolute value, for the higher quantiles. This demonstrates that the covariate effects are linked with a higher size of funding.

In addition, the funding flow presents a significant relationship with GHG emission, whereas the estimated coefficients for the control variables are generally significant and in line with expected results.

The effect of total GHG emissions ( $g h g_{-}$tot) on climate finance is significantly positive in all quantiles. The results reveal that the increase of GHG emissions implies a greater availability of climate funds. Specifically, the effect is stable and mild from the 25th to 75th quantiles and then quickly increases. This outcome implies that the marginal impact of GHG changes from weak to strong. Chaturvedi et al. [16] argue that limited GHG emissions determine additional investments in the electricity-generation sector in the medium and long run, and climate finance plays a crucial role in mitigation. This scenario is even more probable in developing countries in which the synergic effect between ineffective environmental policies and poverty hinders sustainable economic growth. Also, oil supply (oil_sup) shows a significant and negative relationship with climate funds in all quantiles, confirming the presence of the lobbying effect as argued by [5,51].

The share of fossil fuel electricity generation (sh_foss) shows a heterogeneous link with climate funds. It is positive and growing in countries that receive a smaller amount of funding (those included in the 25th and 50th quantile), while it is negative and significant for countries included in the 95th quantile (it is not significant for 75th and 90th quantiles). Greater energy dependence on traditional energy sources limits the deployment of renewables, and the policies that use subsidies are helpful to increase the investments in renewables. Thus, recipient countries require strong support and financial aid to reduce the reliance on traditional energy sources. The only exception concerns countries in the 25th and 50th quantiles, where the effect of the share of fossil fuel is positive. This pattern can 
be justified by the economic structure of the countries-mostly low and lower-middle income-that require funding to support their "green growth". The share of non-hydroelectric renewable generation (sh_nonhydro) has a significant and negative effect on climate finance only for the countries receiving a large quota of climate funds (over the 75th quantile). An increase in this indicator implies a reduction of aid allocated to these countries. It is plausible to assume that a change in policy instruments becomes necessary as soon as a high level of funding is achieved. These results support the conclusion of [7], who argues that "increasing openness and aid, institutional and strategic policy support programs, growth of electricity consumption, and high fossil fuel production appear to delay non-hydro renewable energy diffusion".

The impact of GDP $(l g d p)$ on climate finance is negative and not significant except for the last quantiles. Thus, the GDP effect is only linked with the upper-tail distribution, and an increase in this effect determines a decrease in the funding amount. This outcome suggests a "substitution effect" between international aid and other types of renewable support schemes (i.e., regulatory policies, fiscal incentives, and public investments), and consequently a redesign of the policies and/or incentives to promote electricity generation from renewables [23].

The female population (fem_pop) is a proxy for preferences for greener policy management. It has been shown that women have stronger preferences for environmental issues and protection [45]. Many authors e.g., [64-66] argue that women, due to their responsibilities and functions in households, should be the main beneficiaries of aid and programs to improve living conditions [67]. The estimated coefficients are only significant in the last quantiles and exhibit two patterns. In the 90th quantile, the funding is inversely proportional to the percentage of females, while its effect became positive in the 95th quantile. The discounted negative relation cannot be seen as contrasting with the literature. It is possible that the absolute poverty of the considered countries and the lack of specific programs targeted at women do not allow this improvement. The effect in the last quantile is coherent with the literature.

The effects of energy intensity (ei) are generally negative and not statistically significant except for the 90th quantile, which means that an increase in energy intensity results in a decrease in the funding amount. Therefore, a reduction in energy intensity is only feasible with high funding with a view of improving the entire energy system.

The effects of the percentage of electricity access (acc_el) and electricity consumption (Inel_cons) on total green funding are positive and not statistically significant except for the 50th and 75th quantiles, respectively. This outcome suggests that the funding recipients require more energy consumption to promote economic development, and therefore, they require more economic support. This outcome is also in line with the hypothesis that developing countries, which can access the electrical grid, can also access renewable sources. Most of the funding oriented to reduce climate change has been provided to increase such access through off-grid generation $[17,68]$ and improve the living conditions of rural developing areas $[13,18]$. Hence, to compensate for the absence of electricity-grid access, a financed project is required that provides aid to install off-grid RES power plants without inhibiting the development of commercial renewable energy technology (RET) markets [27,32,69].

Appendix $C$ contains the quantile coefficients plots and allows having a better representation of the variations of the estimated coefficients of the explanatory variables in the quantile distribution.

\subsection{Discussion}

The current environmental degradation has reached alarming levels that require urgent action from around the world. This is particularly true in developing countries that have fewer resources to devote to environmental protection policies [1-3], starting with those concerning the abatement of harmful emissions $[4,5,7]$. To this end, the Fast-Start Finance financial mechanism was launched during the 15th Conference of the Parties (COP15) to counter the effects of climate change and promote economic growth in developing countries. 
To assess how climate change affects the funding distribution in the Fast-Start Finance framework, we propose a quantile regression model. The estimation results confirm a relationship between climate finance, GHG emissions, and oil supply for all quantiles while for electricity generation sources (renewables and fossil) the relationship is heterogeneous. It is negative and significant only for the last quantiles for RES generation and shows a change in the sign for traditional sources. Thus, this outcome highlights the high level of received climate funding and confirms the presence of a lobbying effect and the dependence by fossil fuels in countries receiving a small number of climate funds [5,51].

Results concerning funding distribution confirm that funding level is crucial to reaching the climate finance goals of reducing the effect of anthropogenic activity on the atmosphere and at the same time promoting economic growth [19]. However, the observed funding concentration limits the effectiveness of this policy to a low number of countries (approximately $10 \%$ of the financed countries). Thus, the target countries and the funding amount become important design choices. This assumption provides a basis for the development of environmental plans and promoting the best policies to adopt in decision-making procedures given the implementation of the Paris agreement [70]. Our outcomes also show that the countries that receive more aid typically enjoy preferential channels to donor countries, although the main flows are channeled to emerging economies (particularly the so-called E7). The E7 emerging economies include the 'BRIC' countries (China, India, Brazil, and Russia) plus Mexico, Indonesia, and Turkey.

In addition, the number of projects initiated in developing countries reflects a divergence between the European and US funding distribution strategies. The European countries tend to concentrate aid on a few countries, thus ensuring substantial funding. US funding policies tend to finance a large number of countries but with a low level of economic aid (wide project support approach). The strong divergence in funding distribution policy was confirmed by the Lorenz curve and the Gini Index. They point out that $80 \%$ of the total amount of climate funding is destined for only $10 \%$ of the countries. This outcome and an analysis of funding strategies of donors' countries confirm the concentration of the financial resources and the commitment on the part of European countries.

\section{Conclusions and Policy Implications}

The need to counter the effects of climate change and to limit the impact of anthropogenic activities in the atmosphere was at the base of the Kyoto protocol signed in 1997. Even though it was based on innovative flexible mechanisms, this protocol failed due to the carbon market weaknesses, and inadequate regulatory and policy support.

Nevertheless, in the last decades, international cooperation on environmental policies has become crucial to ensure long-term stability in environmental projects in developing countries. Scholars claim that the effectiveness of climate finance accompanying international cooperation could be further improved [34,36]. Particularly, they underline the need to reach a higher level of coordination among donor states and beneficiaries [14,69], as well as among them and the environmental and development international agencies [20,34] to define priorities that can differ, and minimize the projects' failure probability. Also, a simplification of procedures seems advisable [15,30].

Consistently, this paper tries to shed light on the key factors affecting the distribution of climate finance, and how it is affected by the policies adopted to address climate change and promote sustainable development. To this end, we analyzed the flow of climate funding to assess how the amount and distribution of funding are affected by climate change. The purpose is to provide suggestions to policymakers for evaluating the effectiveness of the flow of funding for environmental plans.

Our results suggest that policy mechanisms that employ Fast-Start Finance should increase the funding available to promote synergy between climate-change mitigation and adaptation measures in developing countries, as already suggested by [71]. Additionally, a wide, differentiated policy spectrum including various incentives and/or grants determined by a large range of factors should be proposed. In this regard, Singer et al. [22] also suggest considering geographical, historical, and resource heterogeneities, because the uneven distribution of fossil fuels and alternative energy resources 
can influence policies that seek to mitigate GHG emissions. In addition, the funding distribution should take into account the development stage of the recipient countries and the level of GHG emissions, thus encouraging the adoption of other national support policies schemes for those countries that reach a higher level of economic development.

This research is based on data on disbursed funds for financing climate-related projects in developing countries. Data about the funds disbursed in 2010 can be considered outdated, but those are the only available at the best of our knowledge available. Other data are reported in the database of international organizations (e.g., OECD and International Monerary Fund), but they are related to committed funds. As previously demonstrated [72], there are sensible deviations between disbursed and committed funds, where the former are systemically lower than the latter. The data availability is a relevant aspect that international institutions and policymakers should take into account to design more effective funding schemes in the future.

Another limitation of the available data concerns GHG emissions. We considered the direct effect of GHG emissions and not other effects related to the entire lifecycle of fossil fuels (extraction, production, and transport). The latter are not readily available and should be calculated for many different cases (different fossil sources, exporting and importing countries, operating technologies, etc.).

Future research on the evaluation of the developmental stage of recipient countries and their whole levels of GHG emissions (to determine a suitable level of climate funding) are required as a basis for determining optimal policies for mitigation and adaptation.

Author Contributions: Abstract, Sections 1 and 2 are contributed jointly by R.P. and I.Q.; Sections 3 and 4 are authored by G.S. Sections 5 and 6 are authored jointly by G.S. and A.T. Conceptualization and paper writing coordination is carried out by G.S. and R.P. All authors have read and agreed to the published version of the manuscript.

Funding: The research has been supported by European Union's Horizon 2020 Research and Innovation Programme 18 under the Marie Skłodowska-Curie European Training Networks (grant agreement ReTraCE No 19 814247).

Conflicts of Interest: The authors declare no conflict of interest.

\section{Appendix A}

\begin{tabular}{lllr}
\hline Iso3 & Country & World Bank Income Group & GHG Tot in 2012 \\
\hline AFG & Afghanistan & Low income & $18,168.86$ \\
AGO & Angola & Upper middle income & $41,657.17$ \\
ARG & Argentina & High incomeOECD & $380,295.32$ \\
ARM & Armenia & Lower middle income & $12,319.39$ \\
AZE & Azerbaijan & Upper middle income & $56,537.08$ \\
BEN & Benin & Low income & $33,533.10$ \\
BGD & Bangladesh & Lower middle income & $183,300.56$ \\
BIH & Bosnia and Herzegovina & Upper middle income & $27,108.40$ \\
BLR & Belarus & Upper middle income & $109,647.24$ \\
BOL & Bolivia & Lower middle income & $621,726.73$ \\
BRA & Brazil & Upper middle income & 2989.42 \\
BWA & Botswana & Upper middle income & $82,110.28$ \\
CHL & Chile & High income & $120,687.89$ \\
CHN & China & Upper middle income & $12,454.71$ \\
CMR & Cameroon & Lower middle income & $100,922.14$ \\
COL & Colombia & Upper middle income & $173,411.77$ \\
CPV & Cape Verde & Lower middle income & 411.33 \\
CRI & Costa Rica & Upper middle income & $12,274.13$ \\
CUB & Cuba & Upper middle income & $52,418.46$ \\
\hline
\end{tabular}




\begin{tabular}{|c|c|c|c|}
\hline Iso3 & Country & World Bank Income Group & GHG Tot in 2012 \\
\hline DOM & Dominican Republic & Upper middle income & $33,395.08$ \\
\hline DZA & Algeria & Upper middle income & $176,471.23$ \\
\hline ECU & Ecuador & Upper middle income & $52,746.57$ \\
\hline EGY & Egypt & Lower middle income & $295,499.75$ \\
\hline ERI & Eritrea & Low income & 4977.89 \\
\hline ETH & Ethiopia & Low income & $185,292.17$ \\
\hline GHA & Ghana & Lower middle income & $107,784.29$ \\
\hline GTM & Guatemala & Lower middle income & $31,515.45$ \\
\hline HND & Honduras & Lower middle income & $20,467.16$ \\
\hline HTI & Haiti & Low income & 8835.47 \\
\hline IDN & Indonesia & Lower middle income & $780,550.76$ \\
\hline IND & India & Lower middle income & $3,002,894.90$ \\
\hline IRN & Iran & Upper middle income & $551,144.13$ \\
\hline JOR & Jordan & Upper middle income & $27,198.60$ \\
\hline KAZ & Kazakhstan & Upper middle income & $366,502.20$ \\
\hline KEN & Kenya & Lower middle income & $54,302.10$ \\
\hline KGZ & Kyrgyzstan & Lower middle income & $13,794.74$ \\
\hline KHM & Cambodia & Low income & $127,399.59$ \\
\hline $\mathrm{LAO}$ & Laos & Lower middle income & $161,718.74$ \\
\hline LBN & Lebanon & Upper middle income & $20,371.97$ \\
\hline LKA & Sri Lanka & Lower middle income & $30,451.83$ \\
\hline LSO & Lesotho & Lower middle income & 3472.71 \\
\hline MAR & Morocco & Lower middle income & $80,436.72$ \\
\hline MDG & Madagascar & Low income & $117,932.60$ \\
\hline MDV & Maldives & Upper middle income & 727.13 \\
\hline MEX & Mexico & Upper middle income & $663,424.95$ \\
\hline MLI & Mali & Low income & $77,437.93$ \\
\hline MNG & Mongolia & Upper middle income & $25,944.26$ \\
\hline $\mathrm{MOZ}$ & Mozambique & Low income & $380,308.29$ \\
\hline MWI & Malawi & Low income & $21,632.13$ \\
\hline MYS & Malaysia & Upper middle income & $279,098.38$ \\
\hline NAM & Namibia & Upper middle income & $38,049.27$ \\
\hline NER & Niger & Low income & $11,460.92$ \\
\hline NGA & Nigeria & Lower middle income & $301,010.13$ \\
\hline NIC & Nicaragua & Lower middle income & $16,323.04$ \\
\hline NPL & Nepal & Low income & $40,762.72$ \\
\hline PAK & Pakistan & Lower middle income & $369,734.58$ \\
\hline PAN & Panama & Upper middle income & $16,248.77$ \\
\hline PER & Peru & Upper middle income & $74,806.96$ \\
\hline PHL & Philippines & Lower middle income & $167,297.55$ \\
\hline PNG & Papua New Guinea & Lower middle income & $11,087.46$ \\
\hline PRY & Paraguay & Upper middle income & $50,843.95$ \\
\hline RWA & Rwanda & Low income & 6689.95 \\
\hline SEN & Senegal & Lower middle income & $54,185.37$ \\
\hline SLV & El Salvador & Lower middle income & $12,577.79$ \\
\hline STP & Sao Tome and Principe & Lower middle income & 195.49 \\
\hline SYR & Syria & Lower middle income & $77,118.71$ \\
\hline THA & Thailand & Upper middle income & $440,411.68$ \\
\hline TJK & Tajikistan & Lower middle income & $15,364.58$ \\
\hline TON & Tonga & Upper middle income & 158.36 \\
\hline TUN & Tunisia & Upper middle income & $39,721.01$ \\
\hline TUR & Turkey & Upper middle income & $445,640.08$ \\
\hline TZA & Tanzania & Low income & $235,353.12$ \\
\hline UGA & Uganda & Low income & $80,725.09$ \\
\hline
\end{tabular}




\begin{tabular}{lllr}
\hline Iso3 & Country & World Bank Income Group & GHG Tot in 2012 \\
\hline UKR & Ukraine & Lower middle income & $404,900.30$ \\
URY & Uruguay & High incomenonOECD & $34,237.83$ \\
VEN & Venezuela & High incomenonOECD & $281,921.37$ \\
VNM & Vietnam & Lower middle income & $310,664.07$ \\
VUT & Vanuatu & Lower middle income & 446.22 \\
YEM & Yemen & Lower middle income & $40,924.63$ \\
ZAF & South Africa & Upper middle income & $450,615.78$ \\
ZMB & Zambia & Lower middle income & $320,254.22$ \\
\hline
\end{tabular}

\section{Appendix B}

Ranking of recipient countries sorted in descending order according to the total amount of received aid and the main donor from which the aid derives. The column "Donor/GT" represents the share of resources of the donor of the total amount of funding disbursed by all developed countries that participate in Climate Finance, while "Recipient/GT" shows the share of the recipient's received resources from the total amount of main disbursed funding. Similarly, the column "Donor/GT donor" shows the share of financed resources of a donor towards its primary beneficiary of the total amount of funding disbursed by the donor. Again similarly, the column "Recipient/GT_recipient" shows the calculated share of allocated funds from a donor of the total received aid.

\begin{tabular}{|c|c|c|c|c|c|c|c|}
\hline Recipient & $\begin{array}{c}\mathbf{n}^{\circ} \text { Financed } \\
\text { Projects }\end{array}$ & $\begin{array}{c}\text { Total of } \\
\text { Recipient }\end{array}$ & Recipient/GT & $\begin{array}{c}\text { Recipient/GT } \\
\text { of Recipient }\end{array}$ & Donor & $\begin{array}{l}\text { Donor/GT } \\
\text { of Donor }\end{array}$ & Donor/GT \\
\hline Turkey & 4 & $\$ 41.71$ & $25.64 \%$ & $99.75 \%$ & France & $98.82 \%$ & $25.88 \%$ \\
\hline India & 17 & $\$ 31.25$ & $19.21 \%$ & $75.26 \%$ & Germany & $58.29 \%$ & $24.80 \%$ \\
\hline China & 59 & $\$ 21.95$ & $13.49 \%$ & $29.54 \%$ & United Kingdom & $40.28 \%$ & $9.89 \%$ \\
\hline Nepal & 10 & $\$ 11.61$ & $7.13 \%$ & $62.03 \%$ & Japan & $38.80 \%$ & $11.41 \%$ \\
\hline Afghanistan & 7 & $\$ 6.42$ & $3.95 \%$ & $50.04 \%$ & Germany & $7.97 \%$ & $24.80 \%$ \\
\hline Peru & 7 & $\$ 4.32$ & $2.66 \%$ & $87.34 \%$ & Belgium & $60.96 \%$ & $3.80 \%$ \\
\hline Indonesia & 15 & $\$ 4.01$ & $2.46 \%$ & $49.41 \%$ & United States & $13.87 \%$ & $8.77 \%$ \\
\hline Uganda & 7 & $\$ 2.65$ & $1.63 \%$ & $80.69 \%$ & Norway & $28.66 \%$ & $4.59 \%$ \\
\hline Philippines & 14 & $\$ 2.21$ & $1.36 \%$ & $38.18 \%$ & Belgium & $13.64 \%$ & $3.80 \%$ \\
\hline Mongolia & 6 & $\$ 2.18$ & $1.34 \%$ & $47.06 \%$ & United States & $7.19 \%$ & $8.77 \%$ \\
\hline Brazil & 19 & $\$ 2.18$ & $1.34 \%$ & $24.68 \%$ & Germany & $1.33 \%$ & $24.80 \%$ \\
\hline Zambia & 3 & $\$ 2.14$ & $1.32 \%$ & $92.21 \%$ & Netherlandddds & $84.41 \%$ & $1.44 \%$ \\
\hline Viet Nam & 14 & $\$ 1.99$ & $1.23 \%$ & $37.51 \%$ & Belgium & $12.09 \%$ & $3.80 \%$ \\
\hline Cambodia & 6 & $\$ 1.82$ & $1.12 \%$ & $67.49 \%$ & Germany & $3.05 \%$ & $24.80 \%$ \\
\hline Bangladesh & 3 & $\$ 1.81$ & $1.11 \%$ & $86.72 \%$ & Switzerland & $32.15 \%$ & $3.00 \%$ \\
\hline Cape Verde & 3 & $\$ 1.61$ & $0.99 \%$ & $42.86 \%$ & Spain & $12.69 \%$ & $3.34 \%$ \\
\hline Ukraine & 6 & $\$ 1.48$ & $0.91 \%$ & $80.12 \%$ & Austria & $43.92 \%$ & $1.66 \%$ \\
\hline Bolivia & 7 & $\$ 1.23$ & $0.75 \%$ & $41.89 \%$ & Japan & $2.77 \%$ & $11.41 \%$ \\
\hline Thailand & 6 & $\$ 1.17$ & $0.72 \%$ & $59.47 \%$ & United States & $4.86 \%$ & $8.77 \%$ \\
\hline Tanzania & 10 & $\$ 1.12$ & $0.69 \%$ & $48.75 \%$ & Norway & $7.30 \%$ & $4.59 \%$ \\
\hline Egypt & 5 & $\$ 1.12$ & $0.69 \%$ & $89.18 \%$ & Japan & $5.37 \%$ & $11.41 \%$ \\
\hline South Africa & 3 & $\$ 1.10$ & $0.67 \%$ & $75.69 \%$ & Switzerland & $17.02 \%$ & $3.00 \%$ \\
\hline Mexico & 8 & $\$ 1.09$ & $0.67 \%$ & $42.00 \%$ & Japan & $2.46 \%$ & $11.41 \%$ \\
\hline Armenia & 1 & $\$ 1.06$ & $0.65 \%$ & $100.00 \%$ & Austria & $39.19 \%$ & $1.66 \%$ \\
\hline Kyrgyz Republic & 3 & $\$ 1.06$ & $0.65 \%$ & $70.70 \%$ & Japan & $4.02 \%$ & $11.41 \%$ \\
\hline Argentina & 11 & $\$ 0.91$ & $0.56 \%$ & $41.90 \%$ & Germany & $0.95 \%$ & $24.80 \%$ \\
\hline Tunisia & 2 & $\$ 0.89$ & $0.55 \%$ & $90.11 \%$ & Germany & $1.99 \%$ & $24.80 \%$ \\
\hline Chile & 4 & $\$ 0.80$ & $0.49 \%$ & $53.75 \%$ & Germany & $1.07 \%$ & $24.80 \%$ \\
\hline Kazakhstan & 1 & $\$ 0.71$ & $0.43 \%$ & $100.00 \%$ & Japan & $3.81 \%$ & $11.41 \%$ \\
\hline Ghana & 5 & $\$ 0.65$ & $0.40 \%$ & $96.37 \%$ & Japan & $3.35 \%$ & $11.41 \%$ \\
\hline Senegal & 5 & $\$ 0.62$ & $0.38 \%$ & $45.90 \%$ & Canada & $43.14 \%$ & $0.41 \%$ \\
\hline Cuba & 6 & $\$ 0.57$ & $0.35 \%$ & $61.10 \%$ & Germany & $0.86 \%$ & $24.80 \%$ \\
\hline Pakistan & 6 & $\$ 0.55$ & $0.34 \%$ & $76.46 \%$ & Switzerland & $8.63 \%$ & $3.00 \%$ \\
\hline Nicaragua & 6 & $\$ 0.47$ & $0.29 \%$ & $44.37 \%$ & Spain & $3.82 \%$ & $3.34 \%$ \\
\hline Maldives & 4 & $\$ 0.46$ & $0.28 \%$ & $79.40 \%$ & Japan & $1.96 \%$ & $11.41 \%$ \\
\hline
\end{tabular}




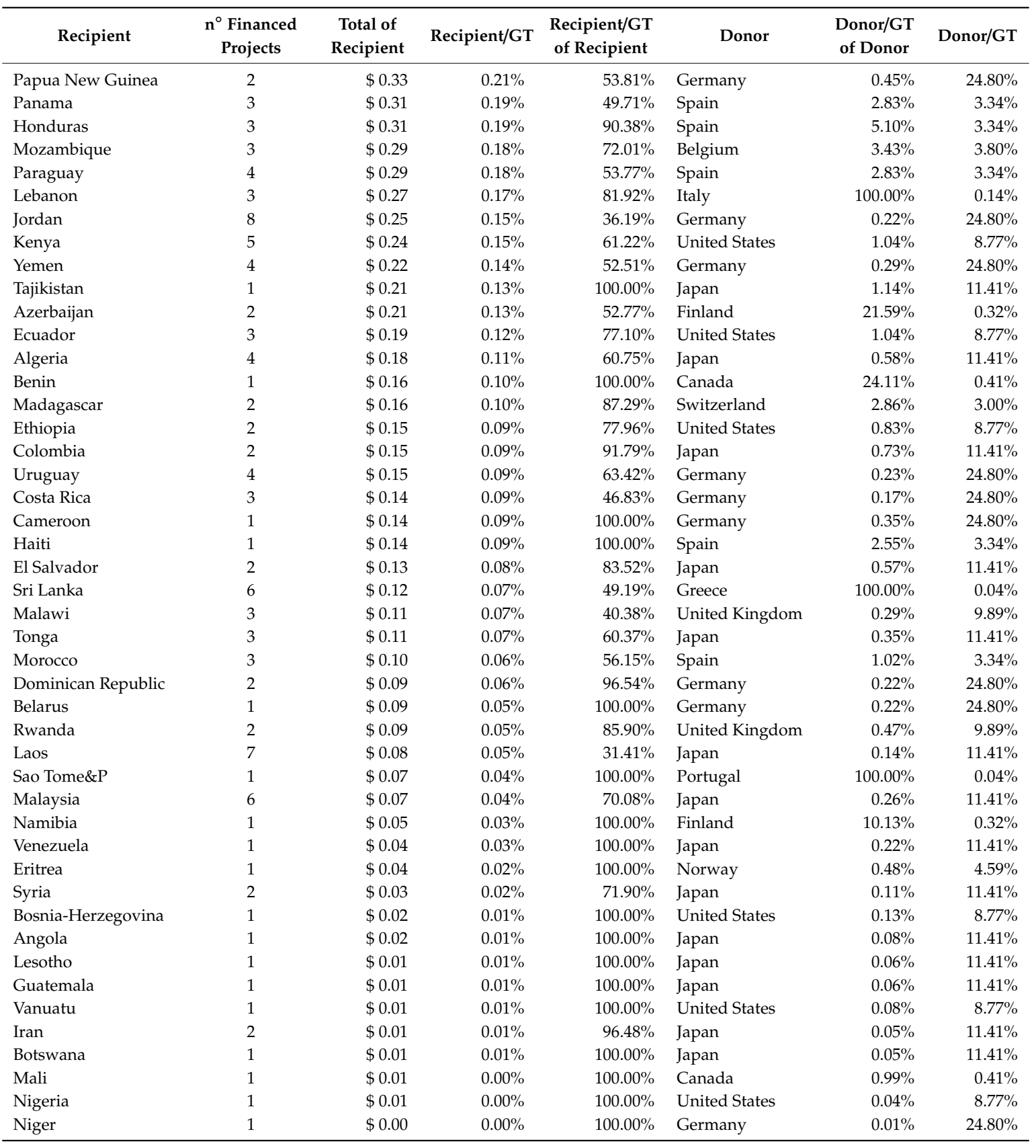

\section{Appendix C}

The subfigures show the estimated coefficients for all different quantiles of dependent variable for the estimated quantile regression model. 


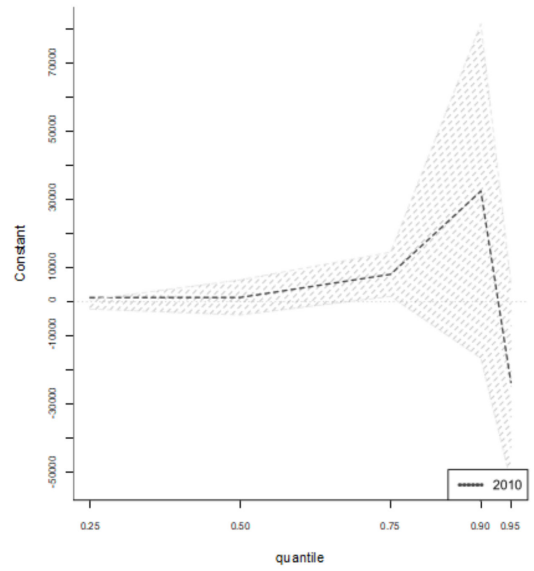

(a)

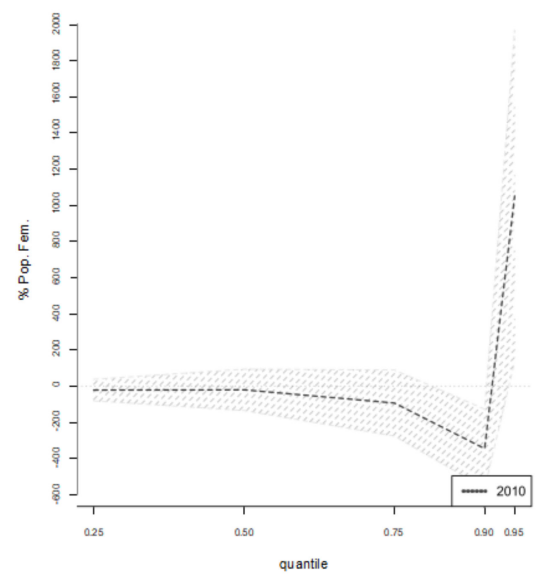

(c)

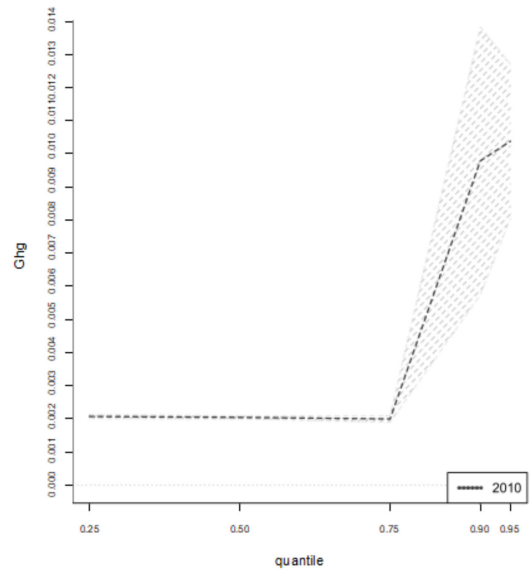

(b)

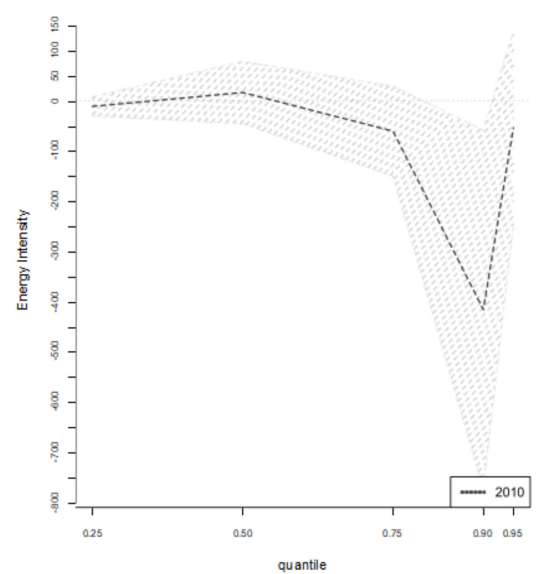

(d)

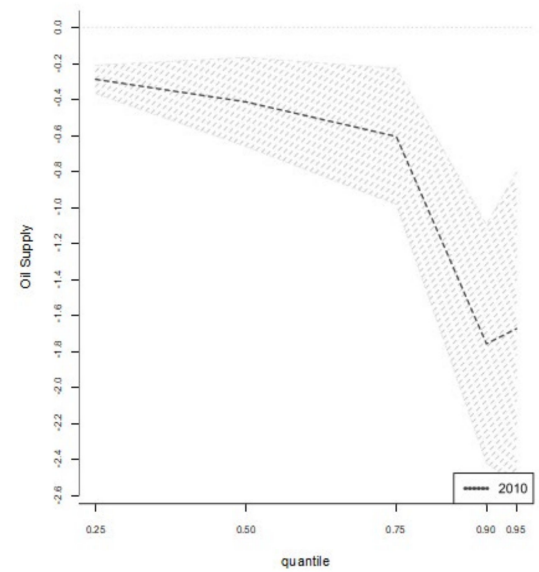

(e)

Figure A1. Cont. 


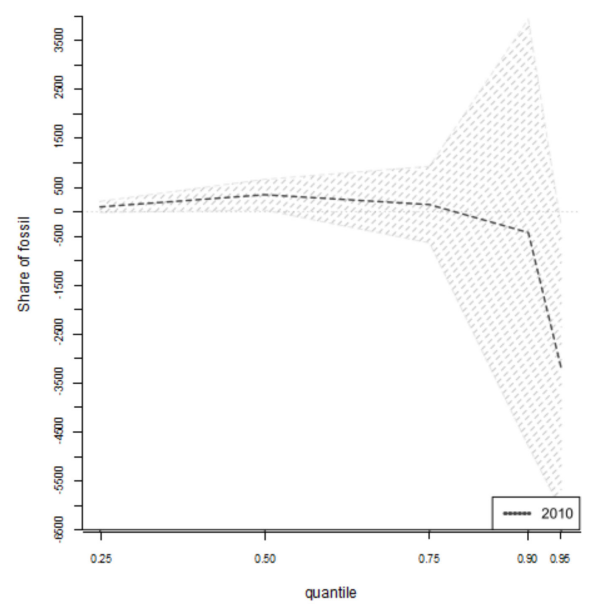

(f)

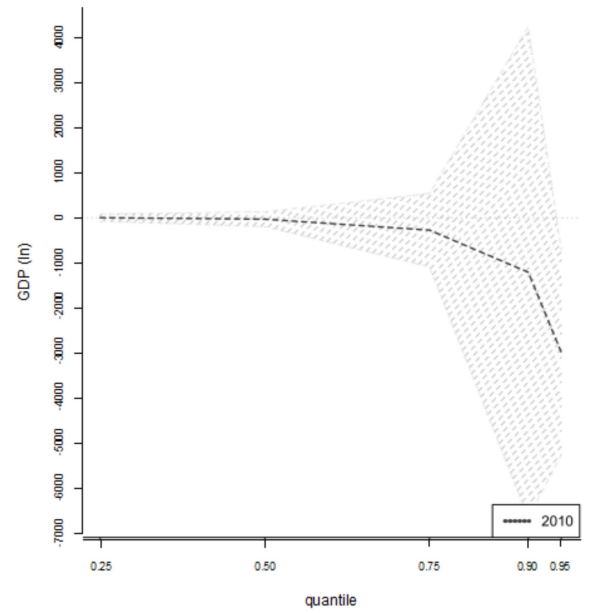

(h)

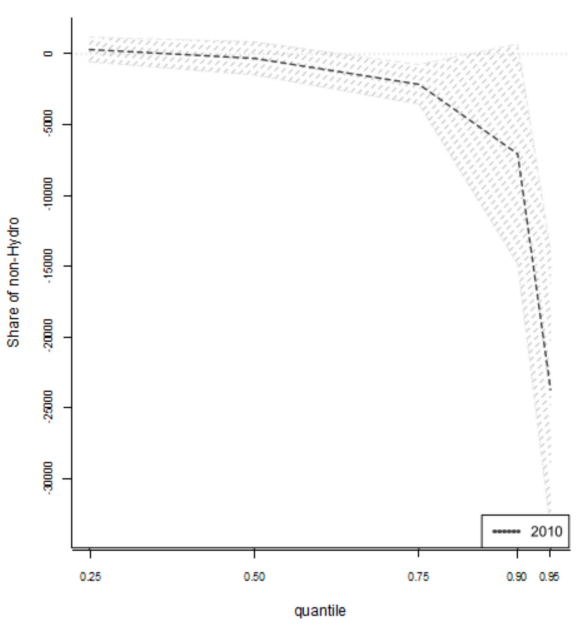

(g)

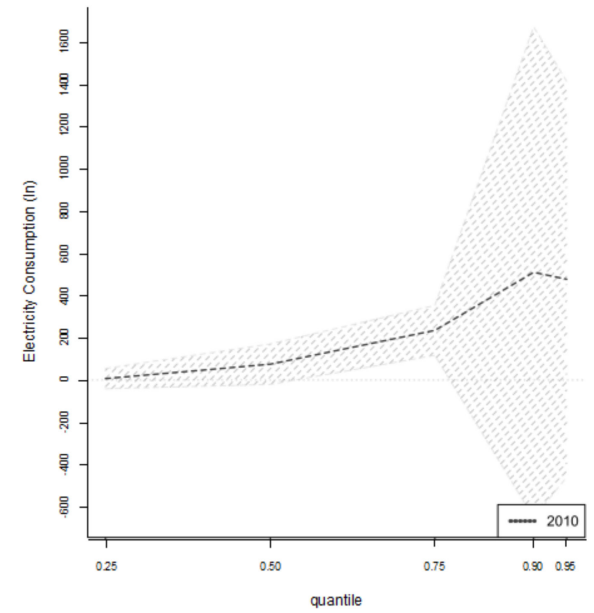

(i)

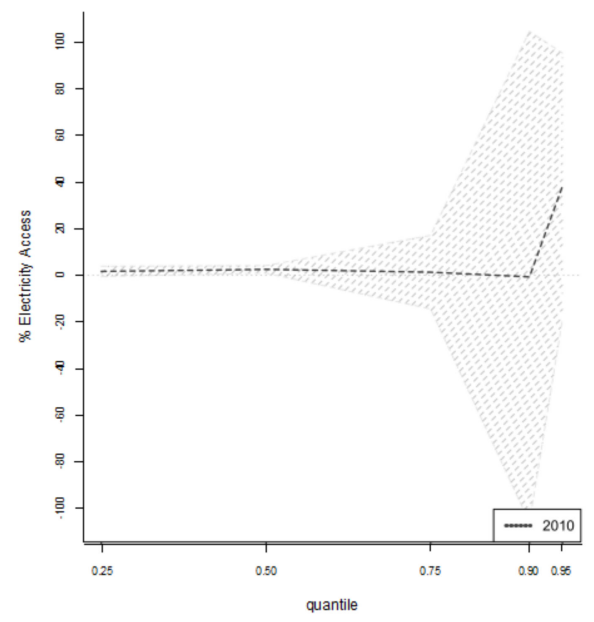

(j)

Figure A1. Quantile coefficients plots. 


\section{References}

1. Randers, J.; Rockström, J.; Stoknes, P.-E.; Goluke, U.; Collste, D.; Cornell, S.E.; Donges, J. Achieving the 17 Sustainable Development Goals within 9 planetary boundaries. Glob. Sustain. 2019. [CrossRef]

2. Goldstein, A.; Turner, W.R.; Spawn, S.A.; Anderson-Teixeira, K.; Cook-Patton, S.C.; Fargione, J.E.; Gibbs, H.K.; Griscom, B.W.; Hewson, J.H.; Howard, J.F.; et al. Protecting irrecoverable carbon in Earth's ecosystems. Nat. Clim. Chang. 2020, 10, 287-295. [CrossRef]

3. Otto, I.M.; Donges, J.F.; Cremades, R.; Bhowmik, A.; Hewitt, R.J.; Lucht, W.; Rockström, J.; Allerberger, F.; McCaffrey, M.; Doe, S.S.; et al. Social tipping dynamics for stabilizing Earth's climate by 2050. Proc. Natl. Acad. Sci. USA 2020, 117, 2354-2365. [CrossRef]

4. Bhattacharyya, S.C. Financing energy access and off-grid electrification: A review of status, options and challenges. Renew. Sustain. Energy Rev. 2020, 20, 462-472. [CrossRef]

5. Marques, A.C.; Fuinhas, J.A.; Manso, J.P. A Quantile approach to identify factors promoting renewable energy in European Countries. Environ. Resour. Econ. 2011, 49, 351-366. [CrossRef]

6. Stern, N.; Rydge, J. The new energy-industrial revolution and international agreement on climate change. Econ. Energy Environ. Policy 2012, 1, 101-120. [CrossRef]

7. Pfeiffer, B.; Mulder, P. Explaining the diffusion of renewable energy technology in developing countries. Energy Econ. 2013, 40, 285-296. [CrossRef]

8. Romano, A.A.; Scandurra, G.; Carfora, A.; Fodor, M. Renewable investments: The impact of green policies in developing and developed countries. Renew. Sustain. Energy Rev. 2017, 68, 738-747. [CrossRef]

9. Gollier, C.; Tirole, J. Negotiating effective institutions against climate change. Econ. Energy Environ. Policy 2015, 4, 5-28. [CrossRef]

10. Timilsina, G.R.; Toman, M. Carbon pricing and cross-border electricity trading for climate change mitigation in South Asia. Econ. Energy Environ. Policy 2018, 7, 111-1244. [CrossRef]

11. Corbera, E.; Jover, N. The undelivered promises of the Clean Development Mechanism: Insights from three projects in Mexico. Carbon Manag. 2012, 3, 39-54. [CrossRef]

12. Giersch, H. Urban Agglomeration and Economic, Egon-Sohmen-Foundation; Springer: Berlin/Heidelberg, Germany, 2012.

13. Khennas, S. Understanding the political economy and key drivers of energy access in addressing national energy access priorities and policies: African perspective. Energy Policy 2012, 47, 21-26. [CrossRef]

14. Bigsten, A.; Tengstam, S. International coordination and the effectiveness of aid. World Dev. 2015, 69, 75-85. [CrossRef]

15. Tol, R.S. The structure of the climate debate. Energy Policy 2017, 104, 431-438. [CrossRef]

16. Chaturvedi, V.; Clarke, L.; Edmonds, J.; Calvin, K.; Kyle, P. Capital investment requirements for greenhouse gas emissions mitigation in power generation on near term to century time scales and global to regional spatial scales. Energy Econ. 2014, 46, 267-278. [CrossRef]

17. Bashir, $\mathrm{M}$. Energy consumption, $\mathrm{CO}_{2}$ emissions and economic growth in developed, emerging and Middle East and North Africa countries. Energy 2019, 179, 232-245.

18. Dranka, G.G.; Ferreira, P.; Vaz, A.; Ismael, F. Cost-effectiveness of energy efficiency investments for high renewable electricity systems. Energy 2020, 198, 117198. [CrossRef]

19. Nakhooda, S.; Norman, M.; Barnard, S.; Watson, C.; Greenhill, R.; Caravani, A.; Withley, S. Climate Finance: Is it Making a Difference? A Review of the Effectiveness of Multilateral Climate Funds; Overseas Development Institute: London, UK, 2014.

20. Pickering, J.; Skovgaard, J.; Kim, S.; Roberts, J.T.; Rossati, D.; Stadelmann, M.; Reich, H. Acting on climate finance pledges: Inter-agency dynamics and relationships with aid in contributor states. World Dev. 2015, 68, 149-162. [CrossRef]

21. Ritchie, J.; Dowlatabadi, H. Why do climate change scenarios return to coal? Energy 2017, 140, $1276-1291$. [CrossRef]

22. Singer, A.M.; Branham, M.; Hutchins, M.G.; Welker, J.; Woodard, D.L.; Badurek, C.A.; Marland, G. The role of $\mathrm{CO} 2$ emissions from large point sources in emissions totals, responsibility, and policy. Environ. Sci. Policy 2014, 44, 190-200. [CrossRef]

23. Carfora, A.; Ronghi, M.; Scandurra, G. The effect of climate finance on greenhouse gas emission: A quantile regression approach. Int. J. Energy Econ. Policy 2017, 7, 185-199. 
24. United Nations Framework Convention on Climate Change. Report of the Conference of the Parties on Its Twenty-First Session, Held in Paris from 30 November to 13 December 2015. Addendum. Part Two: Action Taken by the Conference of the Parties at Its Twenty-First Session; United Nations Office at Geneva: Geneva, Switzerland, 2016.

25. United Nations Framework Convention on Climate Change. Biennial Assessment and Overview of Climate Finance Flows 2014; United Nations: New York, NY, USA, 2014.

26. Kahia, M.; Aïssa, M.S.B.; Charfeddine, L. Impact of renewable and nonrenewable energy consumption on economic growth: New evidence from the MENA Net Oil Exporting Countries (Noecs). Energy 2016, 116, 102-115. [CrossRef]

27. Ramos, C.; Salomé García, A.; Moreno, B.; Díaz, G. Small-scale renewable power technologies are an alternative to reach a sustainable economic growth: Evidence from Spain. Energy 2019, 167, 13-25. [CrossRef]

28. Ndlovu, V.; Inglesi-Lotz, R. The causal relationship between energy and economic growth through research and development (R\&D): The case of BRICS and lessons for South Africa. Energy 2020, 199, 117428. [CrossRef]

29. Keeley, A.R. Renewable Energy in Pacific Small Island Developing States: The role of international aid and the enabling environment from donor's perspectives. J. Clean. Prod. 2016, 30, 29-36. [CrossRef]

30. Espagne, E. Climate Finance at COP21 and After: Lessons Learnt; Technical Report No. 9; CEPII Research Center: Paris, France, 2016.

31. Marzi, S.; Farnia, L.; Dasgupta, S.; Mysiak, J.; Lorenzoni, A. Competence analysis for promoting energy efficiency projects in developing countries: The case of OPEC. Energy 2019, 115996. [CrossRef]

32. Huang, X.; Zhang, H.; Zhang, X. Decarbonising electricity systems in major cities through renewable cooperation-A case study of Beijing and Zhangjiakou. Energy 2020, 190, 116444. [CrossRef]

33. Bazilian, M.; Nussbaumer, P.; Gualberti, G.; Haites, E.; Levi, M.; Siegel, J.; Fenhann, J. Informing the financing of universal energy access: An assessment of current financial flows. Electr. J. 2011, 24, 57-82. [CrossRef]

34. Obradovich, N.; Zimmerman, B. African voters indicate lack of support for climate change policies. Environ. Sci. Policy 2016, 66, 292-298. [CrossRef]

35. Romano, A.A.; Scandurra, G.; Carfora, A.; Ronghi, M. Climate Finance as an Instrument to Promote Green Growth in Developing Countries, Springer Brief Series in Climate Studies; Springer: Berlin/Heidelberg, Germany, 2018. [CrossRef]

36. Przychodzen, W.; Przychodzen, J. Determinants of renewable energy production in transition economies: A panel data approach. Energy 2020, 191. [CrossRef]

37. Halimanjaya, A.; Papyrakis, E. Donor characteristics and the allocation of aid to climate mitigation finance. Clim. Chang. Econ. 2015, 6, 1-25. [CrossRef]

38. Betzold, C.; Weiler, F. Allocation of aid for adaptation to climate change: Do vulnerable countries receive more support? Int. Environ. Agreem. 2017, 17, 17-36. [CrossRef]

39. Bourguignon, F.; Platteau, J.P. The hard challenge of aid coordination. World Dev. 2015, 69, 86-97. [CrossRef]

40. Marquardt, J.; Steinbacher, K.; Schreurs, M. Driving force or forced transition? The role of development cooperation in promoting energy transitions in the Philippines and Morocco. J. Clean. Prod. 2016, 128, 22-33. [CrossRef]

41. Ellis, J.; Caruso, R.; Ockenden, S. Exploring climate finance effectiveness. In Climate Change Expert Group; Technical Report No. 2013/04; Organisation for Economic Co-Operation and Development: Paris, France, 2013.

42. Tirpak, D.; Brown, L.; Ronquillo-Ballesteros, A. Monitoring Climate Finance in Developing Countries: Challenges and Next Steps; World Resources Institute: Washington, DC, USA, 2014.

43. Tierney, M.J.; Nielson, D.L.; Hawkins, D.G.; Roberts, J.T.; Findley, M.G.; Powers, R.M.; Parks, B.; Wilson, S.E.; Hicks, R.L. More dollars than sense: Refining our knowledge of development finance using aiddata. World Dev. 2011, 39, 1891-1906. [CrossRef]

44. Onyeji, I.; Bazilian, M.; Nussbaumer, P. Contextualizing electricity access in sub-Saharan Africa. Energy Sustain. Dev. 2012, 16, 520-527. [CrossRef]

45. Zhao, S.X.; Chan, R.C.; Chan, N.Y.M. Spatial polarization and dynamic pathways of foreign direct investment in China 1990-2009. Geoforum 2012, 43, 836-850. [CrossRef]

46. Agence Française de Développement. AFD's Strategy in Turkey. Available online: http://www.afd.fr/webdav/ site/afd/shared/PUBLICATIONS/THEMATIQUES/AFD_Turquie_GB.pdf (accessed on 16 December 2016). 
47. Koenker, R.; Bassett, G.S.J. Regression quantiles. Econometrica 1978, 46, 33-50. [CrossRef]

48. Buchinsky, M. Recent advances in quantile regression models: A practical guideline for empirical research. J. Hum. Resour. 1998, 33, 88-126. [CrossRef]

49. Ranganai, E.; Van Vuuren, J.O.; De Wet, T. Multiple case high leverage diagnosis in regression quantiles. Commun. Stat. Theory Methods 2014, 43, 3343-3370. [CrossRef]

50. Niu, S.; Jia, Y.; Ye, L.; Dai, R.; Li, N. Does electricity consumption improve residential living status in less developed regions? An empirical analysis using the quantile regression approach. Energy 2016, 95, 550-560. [CrossRef]

51. Marques, A.C.; Fuinhas, J.A. Are public policies towards renewables successful? Evidence from European countries. Renew. Energy 2012, 44, 109-118. [CrossRef]

52. Parente, P.M.; Santos Silva, J. Quantile regression with clustered data. J. Econom. Methods 2016, 5, 1-15. [CrossRef]

53. Kim, T.H.; White, H. Estimation, inference, and specification testing for possibly misspecified quantile regression. Adv. Econom. 2003, 17, 107-132. [CrossRef]

54. Powell, J.L. Least absolute deviations estimation for the censored regression model. J. Econom. 1984, 25, 303-325. [CrossRef]

55. Chamberlain, G. Quantile regression, censoring, and the structure of wages. In Advances in Econometrics: Sixth World Congress; Sims, C.A., Ed.; Cambridge University Press: Cambrigde, UK, 1994; Volume 2, Chapter 5.

56. Lin, B.; $\mathrm{Xu}, \mathrm{B}$. Factors affecting $\mathrm{CO}_{2}$ emissions in China's agriculture sector: A quantile regression. Renew. Sustain. Energy Rev. 2018, 94, 15-27. [CrossRef]

57. Carfora, A.; Scandurra, G. The impact of climate funds on economic growth and their role in substituting fossil energy sources. Energy Policy 2019, 129, 182-192. [CrossRef]

58. Karabee, D.; Pradhan, G.; Nonhebel, S. Human energy and time spent by women using cooking energy systems: A case study of Nepal. Energy 2019, 1821, 493-501.

59. Jakučionytè-Skodienè, M.; Dagiliūtè, R.; Liobikienè, G. Do general pro-environmental behaviour, attitude, and knowledge contribute to energy savings and climate change mitigation in the residential sector? Energy 2020, 193, 116784. [CrossRef]

60. Toklu, E.; Güney, M.S.; IsIk, M.; Comakli, O.; Kaygusuz, K. Energy production, consumption, policies and recent developments in Turkey. Renew. Sustain. Energy Rev. 2010, 14, 1172-1186. [CrossRef]

61. Romano, A.A.; Scandurra, G.; Carfora, A. Probabilities to adopt feed in tariff conditioned to economic transition: A scenario analysis. Renew. Energy 2015, 83, 988-997. [CrossRef]

62. Neumayer, E.; Plümper, T.; Barthel, F. The political economy of natural disaster damage. Glob. Environ. Chang. 2014, 24, 8-19. [CrossRef]

63. Machado, J.A.; Santos Silva, J.M.C. Quantile Regression and Heteroskedasticity, Discussion Paper; Department of Economics, University of Essex: Colchester, UK, 2013; Available online: https://jmcss.som.surrey.ac.uk/JM_ JSS.pdf (accessed on 21 September 2020).

64. Martinot, E.; Chaurey, A.; Lew, D.; Moreira, J.R.; Wamukonya, N. Renewable energy markets in developing countries. Annu. Rev. Energy Environ. 2002, 27, 309-348. [CrossRef]

65. Karekezi, S.; Kithyoma, W. Renewable energy strategies for rural Africa: Is a PV-led renewable energy strategy the right approach for providing modern energy to the rural poor of sub-Saharan Africa? Energy Policy 2002, 30, 1071-1086. [CrossRef]

66. Kanagawa, M.; Nakata, T. Assessment of access to electricity and the socio-economic impacts in rural areas of developing countries. Energy Policy 2008, 36, 2016-2029. [CrossRef]

67. Rao, M.N.; Reddy, B.S. Variations in energy use by Indian households: An analysis of micro level data. Energy 2007, 32, 143-153.

68. Kaygusuz, K. Energy for sustainable development: A case of developing countries. Renew. Sustain. Energy Rev. 2012, 16, 1116-1126. [CrossRef]

69. Chaurey, A.; Krithika, P.R.; Palit, D.; Rakesh, S.; Sovacool, B.K. New partnerships and business models for facilitating energy access. Energy Policy 2012, 47, 48-55. [CrossRef]

70. Organisation for Economic Co-Operation and Development. Climate Finance in 2013-14 and the USD 100 Billion Goal; Organisation for Economic Co-Operation and Development: Paris, France, 2015. 
71. Duguma, L.A.; Wambugu, S.W.; Minang, P.A.; Van Noordwijk, M. A systematic analysis of enabling conditions for synergy between climate change mitigation and adaptation measures in developing countries. Environ. Sci. Policy 2014, 42, 138-148. [CrossRef]

72. Scandurra, G.; Thomas, A.; Passaro, R.; Bencini, J.; Carfora, A. Does climate finance reduce vulnerability in Small Island Developing States? An empirical investigation. J. Clean. Prod. 2020, 256, 120330. [CrossRef]

Publisher's Note: MDPI stays neutral with regard to jurisdictional claims in published maps and institutional affiliations.

(C) 2020 by the authors. Licensee MDPI, Basel, Switzerland. This article is an open access article distributed under the terms and conditions of the Creative Commons Attribution (CC BY) license (http://creativecommons.org/licenses/by/4.0/). 